University of Nebraska - Lincoln

DigitalCommons@University of Nebraska - Lincoln

Finance Department Faculty Publications

Finance Department

$12-2002$

\title{
Monitoring by the Financial Press and Forced CEO Turnover
}

\author{
Kathleen A. Farrell \\ University of Nebraska-Lincoln, kfarrell2@unl.edu \\ David A. Whidbee \\ Washington State University, dwhidbee@mail.wsu.edu
}

Follow this and additional works at: https://digitalcommons.unl.edu/financefacpub

Part of the Finance and Financial Management Commons

Farrell, Kathleen A. and Whidbee, David A., "Monitoring by the Financial Press and Forced CEO Turnover" (2002). Finance Department Faculty Publications. 20.

https://digitalcommons.unl.edu/financefacpub/20

This Article is brought to you for free and open access by the Finance Department at DigitalCommons@University of Nebraska - Lincoln. It has been accepted for inclusion in Finance Department Faculty Publications by an authorized administrator of DigitalCommons@University of Nebraska - Lincoln. 


\title{
Monitoring by the Financial Press and Forced CEO Turnover
}

\author{
Kathleen A. Farrell \\ Department of Finance, College of Business, \\ University of Nebraska-Lincoln, Lincoln, NE, USA \\ David A. Whidbee \\ Department of Finance, Insurance, and Real Estate, \\ College of Business and Economics, \\ Washington State University, Pullman, WA 99164-4746, USA \\ Corresponding author - D. A. Whidbee, \\ tel 509 335-3098, fax 509 335-3857, e-mail whidbee@wsu.edu
}

\begin{abstract}
This paper examines Wall Street Journal news stories about 79 firms that forced CEO turnover and a matched sample of firms that did not force CEO turnover. In the two years prior to turnover, firms in the forced-turnover sample were the subjects of $76 \%$ more news stories about poor firm performance despite being from the same industry, of similar size, and similar performance as a sample of matched firms. Overall, the evidence suggests that scrutiny of poor firm performance by the financial press increases the likelihood of forced CEO turnover.
\end{abstract}

Keywords: CEO turnover, corporate governance, earnings announcements

\section{Introduction}

We examine the coverage of firm events by the Wall Street Journal (WSJ) to determine whether WSJ coverage influences the board's decision to remove a CEO. Specifically, we examine whether WSJ coverage of firm performance influences the likelihood of forced CEO turnover. The WSJ commonly reports on the earnings of firms in its "Digest of Corporate Earnings Reports" section. Less com- 
monly, the WSJ comments on a company's earnings report by pointing out earnings increases or decreases and discussing the reasons for the increase or decrease in a separate news article. The focus of this paper is on whether this latter form of monitoring by the WSJ is related to the incidence of CEO turnover. ${ }^{1}$

There are several reasons why WSJ coverage of a firm's poor performance might be associated with an increased likelihood of CEO turnover. First, Lowenstein $(1996,1999)$ argues that the media influences corporate boards to be more effective because it creates fear that shareholders will sell their shares in response to negative press coverage. He cites several examples of media coverage putting pressure on corporate boards to make changes in their firm's operations or management. Second, Fama (1980) and Fama and Jensen (1983) argue that outside directors have an incentive to be effective monitors of senior managers to signal to shareholders and labor markets their value as experts in decision control. Negative media coverage of firm performance may affect director reputations and create an incentive for directors to remove the CEO in an effort to salvage their reputations. Third, Sutton and Galunic (1996) suggest that scrutiny of business leaders can lead to constant distraction that interferes with their thought and action. Scrutiny, therefore, can reduce the business leader's ability to be an effective leader. ${ }^{2}$ Such business leaders may be more likely to resign or be forced to resign.

Using a sample of 79 firms that forced CEO turnovers between 1982 and 1997 and a matched sample of firms in the same industry, of similar size, and similar performance that do not forcibly remove their CEO, we examine the frequency of various news events, including performance changes, in the WSJ Index in the two years prior to turnover and the two years after turnover. We also examine whether the decisions made by fired CEOs differ significantly from decisions made by matched-sample CEOs. Khanna and Poulsen (1995) find that the decisions made by firms that file for Chapter 11 bankruptcy are not significantly different from the decisions made by a matched sample of firms that do not file Chapter 11. Their results suggest that the poor performance of the Chapter 11 firms is not due to poor decision making by the CEOs. We examine whether the decisions made by fired CEOs differ from the decisions made by matched-sample CEOs. If the fired CEOs did make bad decisions relative to the matched-sample CEOs, then we expect to find that the nature and type of decisions made by the fired CEOs influences the likelihood of CEO turnover. In addition, the share price response to these decisions should be negative when compared to the share price response to decisions announced by surviving CEOs.

The results suggest that CEOs in the forced-turnover sample make decisions that are similar to the matched-sample firm CEOs. Prior to turnover, there are

1 The WSJ may tend to over-report on some firms and under-report on others. We attempt to control for any biases in the WSJ's reporting by using a matched-sample methodology and controlling for other factors that might influence the WSJ's reporting on a firm.

2 Sutton and Galunic (1996) suggest five consequences of scrutiny including, for example, frequent delays in ongoing tasks; attention and effort devoted toward symbolic activities; and attention and effort diverted away from learning and creativity. 
no meaningful differences in the number of acquisition, expansions, new debt, loan extensions, stock issues, and stock buybacks announced by the two samples. The only significant difference in manager decisions, as reported in the WSJ, is that firms in the forced-turnover sample were the subjects of $62 \%$ more news stories about asset sales, layoffs, and downsizing than the matched sample. After controlling for other factors associated with CEO turnover, however, the number of these types of decisions is not significant in explaining CEO turnover. Further, the market responses to the various decisions are not significantly different across the two samples. These results suggest that while both samples are performing poorly, managers in the forced-turnover sample were making more potentially unpopular decisions than managers in the matched sample. However, these decisions do not appear to increase the likelihood of CEO turnover.

Our analysis of WSJ reporting on firm performance finds significant differences in the number of news stories about declining earnings during the two years prior to turnover. The forced-turnover sample firms were the subjects of $76 \%$ more declining earnings stories than the matched-sample firms. Even after controlling for several measures of firm performance and other factors associated with CEO turnover, we find a statistically significant relation between WSJ reporting on poor firm performance and the likelihood of CEO turnover. Our results suggest that increased scrutiny of firm performance by the financial press puts pressure on the board to remove the CEO. This is consistent with the financial press offsetting some of the free rider problems associated with diffuse share ownership in publicly traded corporations by holding managers publicly accountable for poor firm performance.

The remainder of the paper is as follows. Section 2 discusses the reasons why financial press scrutiny may increase the likelihood of CEO turnover. Section 3 describes the sample. Section 4 presents the empirical analysis. Finally, Section 5 concludes the paper.

\section{Scrutiny by the financial press and CEO turnover}

The literature on the relation between CEO turnover and firm performance indicates that poor firm performance by itself does not necessarily lead to CEO turnover. Weisbach (1988) finds that CEO turnover following poor firm performance is most likely to occur in firms that have a board of directors that is dominated by outsiders. Others provide evidence that the pressure to replace a poorly performing CEO can also come from takeover markets (Martin and McConnell, 1991), institutional investors (Parrino et al., 2000) and outside blockholders (Denis and Serrano, 1996). In this section, we discuss the reasons why financial press scrutiny can also influence the board's decision to remove a CEO from office.

There is substantial evidence that media attention affects how others view individuals and organizations. One way media attention affects perceptions is by deciding on what issues, events, people, and organizations are newsworthy, thereby focusing attention on some issues and distracting attention away from other subjects (Price and Tewksbury, 1997). For example, Pan and Kosicki 
(1997) find evidence that those issues receiving the most media coverage establish the basis by which most citizens judge the performance of political leaders. Media attention also affects perceptions by the manner in which the issue or event is presented (Gamson, 1992). Price et al. (1997) show that readers' response to a news story is a function of the manner in which the issue or event is presented.

In addition, there is substantial evidence that media attention, or the threat of media attention, affects the behavior of individuals and organizations. For example, Flynn (2000) reports that media attention prolongs the duration of labor strikes by increasing the feelings of personal responsibility and accountability for the parties involved. Hence, the parties to a strike assume more rigid positions when their positions are made public. In another context, Cavender and Mulcahy (1998) discuss how the threat of media coverage and the need to maintain a positive corporate image can deter corporations from engaging in corporate crime. In addition, the broader WSJ coverage of poorly performing firms may exacerbate operating problems at these firms by harming relations with suppliers, customers, lenders, etc. For example, negative financial press may cause customers to be wary of a product if reliable after-sales-service is important. Similarly, the negative financial press may cause suppliers and/or lenders to tighten credit policies at a time when a firm can least afford it.

Lowenstein $(1996,1999)$ argues that the financial press, along with financial analysts and other commentators, has forced corporate boards to become more active and independent. According to his arguments, the financial transparency created by mandatory disclosure requirements enhances corporate governance in the United States by providing the financial press with the information necessary to meaningfully comment on firm performance. Lowenstein (1999) argues that "the potential for adverse publicity compensates for the damage inflicted under the so-called free rider doctrine, which says that if there are too many shareholders then none of them will bother to become active." According to these arguments, increased scrutiny of firms by the financial press, analysts, and others pressures boards to be more effective because of the fear that bad publicity will cause a decline in firm value.

In addition, Fama (1980) and Fama and Jensen (1983) argue that outside directors have an incentive to serve as effective monitors of senior managers to signal shareholders and labor markets their value as experts in decision control. Empirical evidence confirms that outside directors, in some circumstances, perform an important monitoring function (e.g., Weisbach, 1988; Brickley and James, 1987; Byrd and Hickman, 1992; Brickley et al., 1994). Further, Farrell and Whidbee (2000) find evidence that outside directors are rewarded with additional outside directorships when they remove a poorly performing CEO and replace him or her with a CEO that improves firm performance. Directors may perceive that their reputations are adversely affected if the firm is the subject of a significant number of unfavorable WSJ news items. Directors of firms that receive unfavorable coverage of firm performance might remove the CEO in an effort to improve firm performance and avoid continued bad publicity and damage to their reputations. 
Finally, one of the CEO's responsibilities is to influence the investing public's perception of the firm by fostering a positive corporate image. Unfavorable coverage of the firm's performance detracts from this image and may reflect poorly on the CEO's abilities. A CEO that does a poor job of influencing media coverage may face an increased likelihood of being fired. If we consider the WSJ's coverage of poor firm performance an indicator of the CEO's ability to influence the media, then we can expect a greater incidence of CEO turnover in those firms that are the subjects of more WSJ news items about poor firm performance.

In sum, the reporting by the WSJ on poor firm performance may influence the board of director's decision of whether or not to remove a poorly performing CEO. Extant literature suggests that forced CEO turnover can result from external pressures, such as takeover markets, institutional investors, and outside blockholders. In addition, the financial press, especially the WSJ, may influence the board of directors to force CEO turnover by drawing attention to a firm's poor performance.

\section{Sample design}

We identify CEO turnovers using the Forbes Annual Survey of Compensation for the 1981-1993 period and the Execucomp database for the 1994-1997 period. ${ }^{3}$ After excluding regulated firms, CEOs that were in office for less than two years, and turnovers that were not announced in the WSJ, we identified 148 forced CEO turnovers. ${ }^{4}$ A turnover is classified as forced if the WSJ article discussing the departure mentions pressure from the board of directors, resignation, scandal, reorganization, demotion, policy or personality disagreement, or poor performance. ${ }^{5}$ From the 148 forced turnovers, we lose 69 additional turnovers due to an inability to find an appropriate matching firm, missing proxy statements, or missing Compustat data. The final sample consists of 79 forced CEO turnovers associated with 76 firms.

\subsection{Matched sample}

To test for whether reporting on poor firm performance by the financial press increases the likelihood of CEO turnover, we select a matched sample of firms that do not force CEO turnover. To form the matched sample, we search for companies that satisfy the following criteria:

3 Murphy and Zimmerman (1993) note that sample selections based on the Forbes 500 may bias a sample toward large, surviving, and growing firms. When possible, we include firms that drop out of the Forbes sample before the end of the 1993 period, as well as firms that appear in Forbes at any time during the sample period.

4 We place these restrictions on the sample because of the significant differences between regulated firms and unregulated firms as documented by Baysinger and Zardkoohi (1986) and Subrahmanyam et al. (1997). The two-year restriction is intended to eliminate turnovers of interim CEOs.

5 We use criteria similar to Blackwell and Farrell (1999) in defining forced departure who combine the criteria used by Weisbach (1988), Gilson (1989) and Parrino (1997). 
1. The matching firm operates in the same two-digit standard industrial classification (SIC) code as the forced-turnover firm. ${ }^{6}$

2. The matching firm is included in the Forbes Annual Survey of Compensation for the 1981-1993 period or the Execucomp database for the 1994-1997 period.

3. The matching firm's total assets are between $50 \%$ and $150 \%$ of the forced-turnover firm's total assets.

4. The matching firm's performance is similar to the forced-turnover firm's performance, as measured by annual stock returns. ${ }^{7}$

5. The matching firm does not experience a forced-turnover for five years surrounding the turnover date of the forced-turnover firm.

We use an industry- and size-matched sample to mitigate the influence of industry and size on CEO turnover and the types of decisions made and announced in the WSJ. Thompson et al. (1987) find that larger firms receive greater coverage in the WSJ than smaller firms. Parrino (1997) finds evidence that the availability of a strong outside candidate, frequently those with experience in the same or similar industry, is an important consideration in the decision by the board to replace a poor CEO. Using an industry-matched sample helps to control for the availability of a strong outside candidate as a factor that may influence the likelihood of turnover.

In addition, the sample is matched on performance because previous research documents a negative relation between forced-turnover and firm performance (e.g., Gilson, 1989; Weisbach, 1988; Parrino, 1997). Since we are interested in the factors that influence the likelihood that a CEO will be fired, the matched sample includes only firms that did not fire their CEO during the five fiscal years surrounding the turnover date of the forced-turnover sample firm. The matched sample includes firms that experience either no turnover or only voluntary turnovers.

\subsection{Comparison of the forced-turnover and matched firms}

The median characteristics of the turnover and the matched-sample firms are shown in Table $1 .^{8}$ Firms in the turnover sample are, on average, slightly larger

6 We use two-digit SIC codes as the sample of possible matches using three- or four-digit SIC codes is too small when combined with our other matching criteria. In addition, Clark (1989) finds that SIC codes are more effective at dividing firms into broad industrial groups than at dividing firms into three- and four-digit segments to more closely represent economic markets.

7 After identifying all potential matched-sample firms using two-digit SIC codes and asset size, the average annual stock return during the two years prior to turnover for the forced-turnover sample firm was compared to the average annual stock return over the same period for each of the potential matched-sample firms. The potential matched-sample firms were then ranked based on the absolute value of the difference in their performance and the turnover firm's performance, with those firms having the smallest difference being ranked first. We then selected the highest ranked firm that does not experience a forced-turnover for five years surrounding the turnover date of the forced-turnover firm.

8 Table 1 reports medians, but means are available from the authors. The results of paired difference tests are very similar regardless of whether we use the parametric $t$-statistic or the non-parametric Wilcoxon signed-rank statistic. 
Table I. Medians for 79 firms with forced CEO turnover and 79 matching firms without forced CEO turnover

\begin{tabular}{llll}
\hline Variable & $\begin{array}{c}\text { Medians for } \\
\text { firms that forced } \\
\text { CEO turnover }\end{array}$ & $\begin{array}{c}\text { Medians for } \\
\text { firms that did } \\
\text { not force CEO }\end{array}$ & $\begin{array}{c}\text { Wilcoxon } \\
\text { signed-rank } \\
\text { statistic } \\
\text { turnover }\end{array}$ \\
\hline
\end{tabular}

Pre-turnover financial characteristics ${ }^{\text {b }}$

Sales (in billions)

$\begin{array}{ccr}\$ 1.955 & \$ 1.880 & 366.0 * \\ \$ 1.331 & \$ 1.144 & 327.0 * \\ & & \\ 1.14 \% & 1.63 \% & -173.0 \\ 0.84 \% & 0.46 \% & 315.5 \\ 4.00 & 4.00 & 30.0 \\ 2.00 & 1.00 & \\ & & \\ -20.78 \% & -13.27 \% & -77.5 \\ -10.43 \% & -9.38 \% & -308.0\end{array}$

Market value of equity (in billions)

Performance during two years prior to turnover

Industry-adjusted ROAA ${ }^{c}$

Change in industry-adjusted ROAA ${ }^{c}$

Number of quarters with a decline in earnings ${ }^{d}$

Number of quarters with a large decline in earnings ${ }^{d}$

$503.0 * * *$

Average quarterly earnings surprise ${ }^{e}$

Average annual market-adjusted stock returns ${ }^{f}$

$-10.43 \%$

$-9.38 \%$

$-308.0$

Pre-turnover ownership structure

Share ownership by officers of the firm

Share ownership by affiliated outside directors

Share ownership by independent outside directors

Share ownership by institutional investors

$\begin{array}{rrr}0.86 \% & 1.26 \% & -373.0 * \\ 0.07 \% & 0.08 \% & -146.0 \\ 0.06 \% & 0.07 \% & -125.0 \\ 51.84 \% & 50.99 \% & 42.0\end{array}$

Pre-turnover corporate governance

Officer board membership

$\begin{array}{llr}25.00 \% & 25.00 \% & 128.0 \\ 22.22 \% & 21.43 \% & -73.5 \\ 50.00 \% & 50.00 \% & 62.5 \\ 12.00 & 12.00 & -12.5\end{array}$

Affiliated outside board membership

Independent outside board membership

Board size

12.00

$-12.5$

Pre-turnover analyst following $\mathrm{g}$

Number of analysts one year prior to turnover

10.50

10.00

179.5

Number of analysts at month of turnover

12.00

10.00

200.5

Performance during two years after turnover

Industry-adjusted ROAA after turnover (two years) ${ }^{\mathrm{h}}$

Average annual market-adjusted stock returns ${ }^{f}$

$-2.08 \%$

$-0.88 \%$

254.5

a The Wilcoxon signed-rank statistic tests the null hypothesis that the two samples have the same median. The statistics are based on paired differences between the two samples. Tests based on $t$-statistics yield very similar results.

b Sales and market value of equity are measured as of the end of the fiscal year preceding turnover and expressed in constant 1990 dollars.

(continued on next page) 


\section{Table I (continued)}

c Pre-turnover return on average assets (ROAA) is measured during the last two years ending prior to CEO turnover. It is industry adjusted by differencing from industry medians using two-digit SIC codes. Changes in ROAA are based on changes in the industry-adjusted performance measures during the two years prior to CEO turnover. We were able to calculate these changes for only 73 of the firms in the forced-turnover sample and 72 of the firms in the matched sample due to insufficient data. Calculating the changes requires three years of pre-turnover data, which was not available for some of the firms.

$d$ The number of quarters with a decline in earnings is measured during the eight quarters that end prior to CEO turnover. The number of quarters with a large decline in earnings is based on whether the decline in earnings represented more than a $50 \%$ decline relative to the previous quarter or, in cases where the previous quarter showed a loss, if losses increased by more than $100 \%$.

e Earnings surprise data are the percentage difference between actual quarterly earnings and forecasted earnings. Forecasted earnings are from Zachs Investment Research. Quarterly earnings forecasts were available for only 42 of the forced-turnover firms and 43 of the matched firms. The signed-rank statistic is based on 38 matched pairs.

$f$ Stock returns are market-adjusted using the CRSP NYSE/AMEX/Nasdaq value-weighted index.

$g$ Analyst following data are from Zachs Investment Research and reflect the number of analysts in a given month making earnings predictions for the fiscal year. Analyst following data were available for only 66 forced-turnover firms and 66 matched firms. The signed-rank statistic is based on 65 matched pairs.

$\mathrm{h}$ Post-turnover ROAA is measured during the two years that begin after CEO turnover.

* Difference is statistically significant at the $10 \%$ level.

** Difference is statistically significant at the $5 \%$ level.

*** Difference is statistically significant at the $\mathrm{I} \%$ level.

than matched-sample firms as measured by sales and market value of equity. To determine the sensitivity of our matching criteria to the choice of firm performance measure, we calculate several alternative performance measures for the two years prior to CEO turnover, including: industry-adjusted return on average assets (ROAA) ${ }^{9}$; the change in industry adjusted ROAA; the number of quarters the firm experiences a decline in earnings; the number of quarters the firm experiences a large decline in earnings ${ }^{10}$; the average quarterly earnings surprise ${ }^{11}$; and market-adjusted stock returns. We find that the forced-turnover and matchedsample firms perform similarly prior to the turnover date for all of the performance measures except the number of quarters in which the firm experiences a large decline in earnings.

We also compare the ownership structure and corporate governance characteristics of the turnover and matched samples. These characteristics are based on

9 ROAA data are industry adjusted by differencing them from industry medians based on twodigit SIC codes.

10 The number of quarters with a large decline in earnings is based on whether the decline in earnings was more than a $50 \%$ decline relative to the previous quarter or, in cases where the previous quarter showed a loss, if losses increased by more than $100 \%$.

11 Earnings surprise data are the percentage difference between actual quarterly earnings and forecasted earnings. Forecasted earnings are from Zachs Investment Research. 
information contained in the proxy statement filed just prior to turnover. Previous studies find that ownership by officers and directors' influences the performance-turnover relation. Denis et al. (1997) find that even after controlling for performance, the probability of top executive turnover is negatively related to the ownership stake of officers and directors. After controlling for firm performance, Denis and Denis (1994) find that majority-owned firms experience significantly lower rates of top management turnover than a control sample of diffusely held firms. Mikkelson and Partch (1997) also document a negative relation between top executive turnover and the equity ownership of officers and directors. As shown in Table 1, officers in the matched sample own slightly more firm equity than in the forced-turnover sample.

Parrino et al. (2000) find evidence that institutional investors tend to sell shares in firms that subsequently force CEO turnover, suggesting that institutional selling pressures the board to remove a poorly performing CEO. We find no significant difference between the institutional ownership of the turnover and matched firms in our sample. Similarly, there are no significant differences in the number of analysts following the firms.

Weisbach (1988) finds a stronger relation exists between turnover and poor performance, as measured by earnings or stock returns, when the board is dominated by outside directors. Hermalin and Weisbach (1988) find evidence that board composition is related to the CEO succession process. Again, Table 1 illustrates that both the matched sample and forced-turnover sample have similar board composition with approximately $25 \%$ of the members representing management, $22 \%$ representing affiliated outsiders and $50 \%$ representing independent outsiders. ${ }^{12}$

Overall, Table 1 indicates that, despite our matching criteria, the forced-turnover firms are slightly larger, have lower inside ownership, and experienced more large declines in earnings during the two years prior to turnover than the matched-sample firms. We control for these differences and other potential determinants of CEO turnover in the empirical analysis that follows.

\section{Empirical analysis}

We collect media coverage information for the two groups of firms by examining the WSJ Index for announcements and news reports about manager decisions, legal actions against the firm, proxy contests, and positive or negative earnings announcements. Similar to Khanna and Poulsen (1995), we identify the following manager decisions: changes in top management (which includes chairmen, presidents, chief financial officers and chief operating officers); plant closings, layoffs, asset sales or downsizing; acquisitions and expansions; lending arrangements and new debt; debt swaps; issuance of equity; and stock buybacks.

12 We define affiliated outside directors as any director with a specified business relation with the firm, retirees, or family members and independent outside directors as having no affiliation with the firm. Our definition is consistent with Weisbach (1988) and Farrell and Whidbee (2000), among others. 
One potential concern in this analysis is that WSJ reporting of manager decisions may be biased such that some managers' decisions are underreported while other managers receive extensive coverage. However, Yau et al. (1994) find that WSJ-based samples for corporate news items are representative of cases not covered by the WSJ. In addition, we attempt to control for any biases in WSJ reporting of manager decisions using the matched-sample methodology described above.

In addition to the manager decisions announced in the WSJ, we collect data on several non-decision news articles about the firm. The non-decision articles we are most interested in are WSJ news items that comment on a firm's earnings announcements as a measure of the degree of coverage of a firm's performance. Specifically, we searched the WSJ Index for earnings announcements that are accompanied by commentary indicating whether the announced earnings represent an increase or decrease. Earnings announcements that did not explicitly indicate whether the reported earnings represented an increase or decrease were ignored because they do not represent significant monitoring by the WSJ. Earnings announcements accompanied by commentary, however, are indicative of monitoring activity by the WSJ.

Other non-decision articles include announcements of the firm being the target of legal action as a potential indicator of illegal or unethical behavior by senior management and proxy contests as a potential indicator of shareholder dissent. We did not collect information about some common types of announcements. For example, we did not include articles about changes in sales revenue unless the change in revenue was also associated with a change in earnings. Also ignored were subsequent news items about a previously announced event. For example, only the first announcement about an acquisition is included in this analysis. Subsequent announcements (e.g., announcements about the acquisition being completed) are ignored because we only expect the market to respond to new information and we wanted to avoid double-counting of some events.

In an effort to determine whether the market's perception of the quality of management decisions differs between the forced-turnover sample and the matched sample, we estimate the share price response to the decisions announced by the two groups of CEOs. In addition, we estimate the share price response to the non-decision announcements in the WSJ. Single-index market model parameters are estimated over the 170 to 20 days preceding each announcement. From these parameters, we determine abnormal stock returns around the event announcement, reporting the announcement effect as the average cumulative abnormal return (CAR) from the day before the event to the day of the announcement. See Brown and Warner (1985) for a more complete description of the methodology.

\subsection{Summary of news announcements surrounding forced CEO turnover}

Table 2 summarizes the news articles that were published in the WSJ in the four years surrounding forced-turnover for the forced-turnover sample and for the comparable sample period for the matched-sample firms. All of the forced- 
Table 2. Summary of news announcements for 79 firms that forced CEO turnover and 79 matching firms that did not force CEO turnover ${ }^{\mathrm{a}}$

\begin{tabular}{|c|c|c|c|c|c|c|c|}
\hline \multirow[t]{2}{*}{ Type of announcement } & \multicolumn{4}{|c|}{ Firms that forced CEO turnover } & \multicolumn{3}{|c|}{$\begin{array}{l}\text { Matching firms that did not force } \\
\text { CEO turnover }\end{array}$} \\
\hline & \multicolumn{2}{|c|}{$\begin{array}{l}\text { Number } \\
\text { of firms }\end{array}$} & \multirow{2}{*}{$\begin{array}{r}\begin{array}{r}\text { Number } \\
\text { of events }\end{array} \\
121\end{array}$} & \multirow{2}{*}{$\begin{array}{r}\begin{array}{r}\text { Maximum } \\
\text { number } \\
\text { of events } \\
\text { for a firm }\end{array} \\
5\end{array}$} & \multirow{2}{*}{$\begin{array}{r}\text { Number } \\
\text { of firms } \\
36\end{array}$} & \multirow{2}{*}{$\begin{array}{r}\text { Number } \\
\text { of events }\end{array}$} & \multirow{2}{*}{$\begin{array}{r}\begin{array}{r}\text { Maximum } \\
\text { number } \\
\text { of events } \\
\text { for a firm }\end{array} \\
3\end{array}$} \\
\hline Change in top management (I) & & 79 & & & & & \\
\hline Asset sales, layoffs, downsizing ( & (2) & 68 & 320 & 27 & 52 & 198 & 21 \\
\hline Acquisitions or expansions (3) & & 57 & 207 & 15 & 61 & 202 & 15 \\
\hline New debt or loan extensions ( & & 28 & 50 & 5 & 17 & 34 & 6 \\
\hline Issue stock (5) & & 14 & 20 & 3 & 14 & 19 & 4 \\
\hline Stock buyback (6) & & 27 & 38 & 4 & 33 & 42 & 3 \\
\hline Other decisions ${ }^{\mathrm{b}}(7)$ & & 23 & 31 & 3 & 25 & 40 & 5 \\
\hline All decisions $(2,3,4,5,6,7)$ & & 76 & 666 & 30 & 74 & 535 & 36 \\
\hline All “bad” decisions $(2,5)$ & & 69 & 340 & 27 & 55 & 217 & 22 \\
\hline All “good” decisions $(3,4,6)$ & & 67 & 295 & 16 & 69 & 278 & 16 \\
\hline All negative CAR decisions ${ }^{c}$ & & 68 & 318 & 17 & 64 & 256 & 12 \\
\hline All positive CAR decisions ${ }^{c}$ & & 69 & 341 & 18 & 68 & 273 & 25 \\
\hline Target of legal action & & 37 & 83 & 8 & 29 & 51 & 5 \\
\hline Earnings increases & & 57 & 201 & II & 46 & 156 & 11 \\
\hline Earnings decreases & & 60 & 171 & 10 & 46 & 111 & 9 \\
\hline Proxy contests & & 4 & 5 & 2 & 2 & 3 & 2 \\
\hline All announcements & & 79 & $|25|$ & 47 & 78 & 912 & 54 \\
\hline
\end{tabular}

a This table summarizes the frequency of various news announcements in the Wall Street Journal Index for a sample of 79 firms that forced CEO turnover and 79 matching firms that did not force CEO turnover. The number of firms is the number of firms (out of a possible 79) with at least one announcement of the given type. The number of events is the total number of announcements of a given type for either the $\mathbf{7 9}$ firms that forced CEO turnover or the $\mathbf{7 9}$ matching firms that did not force CEO turnover. The announcements were made in the four years surrounding turnover.

b Other decisions include debt-for-equity swaps, debt redemptions, and the adoption of antitakeover charter amendments.

c Positive CAR decisions are those decisions with a cumulative abnormal return over the $(-I, 0)$ event period greater than zero. Negative CAR decisions are those decisions with a cumulative abnormal return over the $(-I, 0)$ event period less than zero.

turnover firms and all but one of the matched-sample firms were the subject of at least one WSJ article during the four years surrounding turnover. The turnover firms had a total of 1251 news articles, which is substantially more than the matched-sample firms, which had only 912 news articles. 
We also develop categories for decisions based on empirical regularities noted in previous studies. We define a category for "bad" decisions as those relating to plant closings, layoffs, asset sales or downsizing, or the issuance of equity. These events are often associated with bad news about a company's performance or growth opportunities and/or are typically associated with a negative market reaction upon their announcement. ${ }^{13}$ Similarly, we define a category of decisions relating to acquisitions and expansions; lending arrangements and new debt; and stock buybacks as "good" decisions. These events are often associated with good news about the company's performance or growth opportunities and/or are typically associated with a positive market reaction upon announcement. ${ }^{14}$ We do not classify top management changes as "good" or "bad" because the reaction to these announcements is a function of the level of top management, firm performance, and whether the turnover is forced or voluntary. Also we exclude other decisions since these announcements include events that are difficult to categorize. For the forced-turnover sample, slightly more than half of the decision announcements are categorized as "bad" while the majority of decision announcements made by the matched sample are categorized as "good."

Our definitions for "good" and "bad" decisions are somewhat arbitrary and subject to debate. To consider the sensitivity of our results to the definitions of "good" and "bad" decisions, we also partition decisions by the cumulative abnormal return associated with each individual decision announcement. In other words, all decision announcements that result in a negative CAR and all decision announcements that result in a positive CAR are placed into separate categories. Based on these classifications, slightly more than half of the decisions announced by both samples resulted in a positive CAR.

The forced-turnover sample firms were the subjects of many more non-decision announcements (target of legal action, earnings increases, earnings decreases, and proxy contests) than the matched-sample firms. Specifically, the forced-turnover firms were the subjects of 171 news items about declining earnings while the matched firms were the subjects of only 111 such news items. Coincidentally, the forced-turnover firms were also the subjects of more news items about increasing earnings (201 versus 156).

In the following section, we examine the share price response to manager decisions and non-decision announcements in an effort to determine the quality of manager decisions as perceived by the market and to assess the market's reaction to the non-decision announcements.

13 For example, Blackwell et al. (1990) find a negative stock market reaction to plant closing announcements. Asquith and Mullins (1986) find a negative stock market reaction to the announcement of seasoned equity issues.

14 For example, James (1987) finds a positive stock price reaction to the announcement of new bank credit agreements and a statistically insignificant reaction to the issuance of private placements of debt or public straight debt. We argue that acquisitions and expansions are indications of growth opportunities available to the firm. 


\subsection{Market reaction to news announcements prior to forced CEO turnover}

The first two columns of Table 3 summarize the market response to the various announcements that took place two years prior to turnover. In general, the market response to individual decision announcements for the forced-turnover sample firms tends not to differ significantly from zero two years prior to turnover. Our results are consistent with several studies that document different market responses to the same types of announcements. For example, Palmon et al. (1997) find that the market response to layoff announcements depends on whether the layoff is a cost cutting measure or a response to product market conditions. Similarly, Akhigbe et al. (1997) find that the market response to corporate debt issues depends on whether the issue is the result of a cash flow shortfall or an increase in firm investments, an increase in firm leverage, or a refinancing of firm debt. James (1987) finds that new debt announcements have varying market responses depending on whether it is bank debt or a straight debt issue.

The only significant reaction to individual news announcements for the forced-turnover sample firms were negative reactions to earning decreases and announcements that these firms are the targets of legal action. ${ }^{15}$ The matchedsample firms experience similar negative and statistically significant reactions to these announcements. The matched-sample firms also experience a statistically significant positive reaction to the small number of stock buybacks announced in the WSJ. The CAR associated with changes in top management is negative and statistically significant for the matched sample, but not significant for the forced-turnover sample. ${ }^{16}$ Overall, both the forced-turnover and matched-sample firms experience CARs that are negative, on average, for all announcements.

None of the differences between the forced-turnover and matched-sample firms are statistically significant. ${ }^{17}$ This is important because it suggests that neither the reasons nor the motivations for the decisions are systematically different for the two groups of firms and that the market does not perceive the forcedturnover sample firms to be making significantly different decisions than the matched-sample firms prior to turnover.

\subsection{Market reaction to news announcements after forced CEO turnover}

In the two years following turnover, the matched-sample firms and the forcedturnover sample firms experience similar market reactions to most individual news announcements and the various news announcement categories. This is shown in the last two columns of Table 3. Reactions to individual news announce-

15 The negative CARs associated with announcements of legal action against the firm are consistent with findings by Karpoff and Lott (1993).

16 Note that we excluded the 79 announcements relating to the forced CEO turnovers in the forced-turnover sample firms.

17 The $t$-statistics associated with the tests for differences in CARs between the turnover and matched samples are not shown in Table 3 but are available from the authors. 


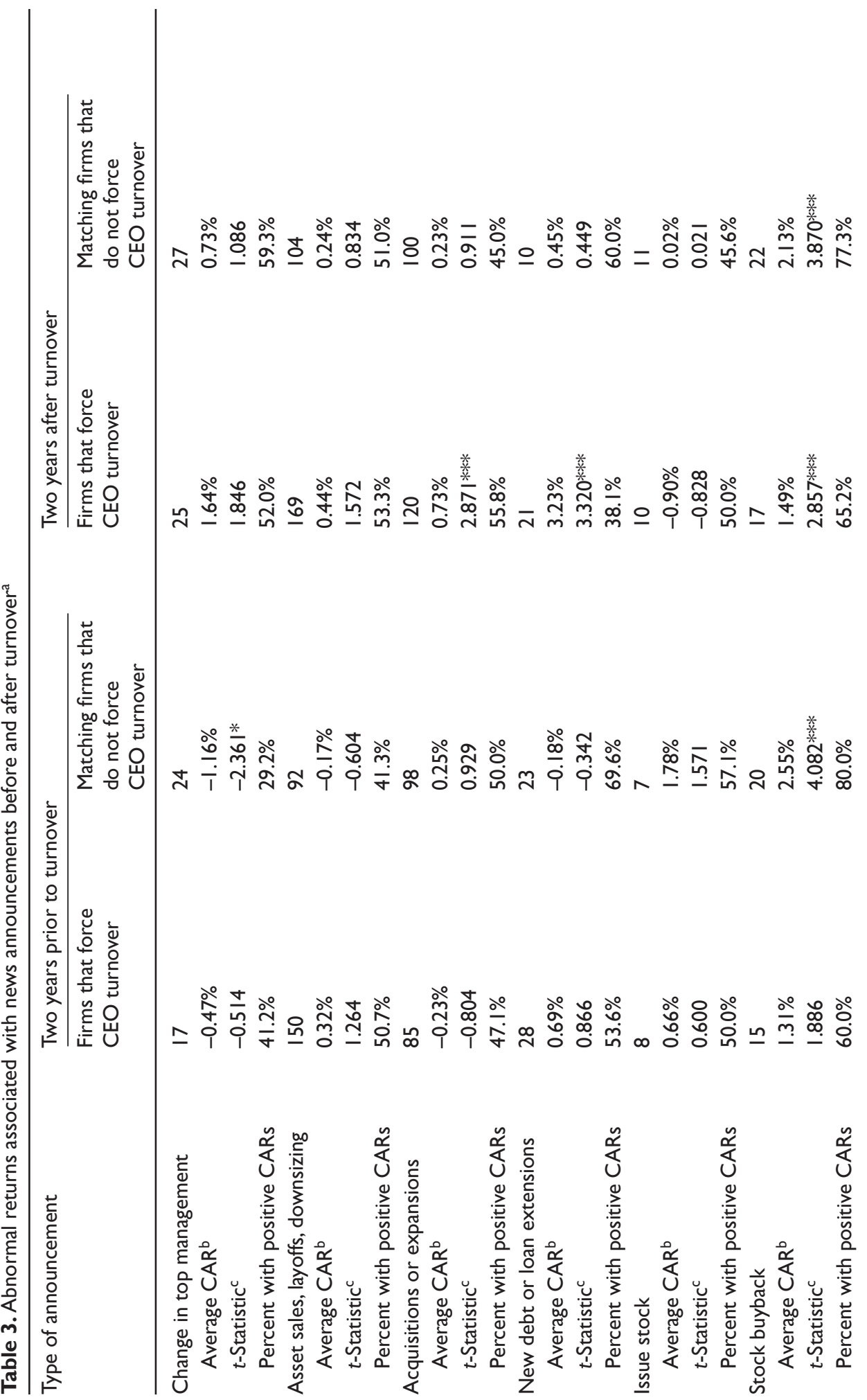




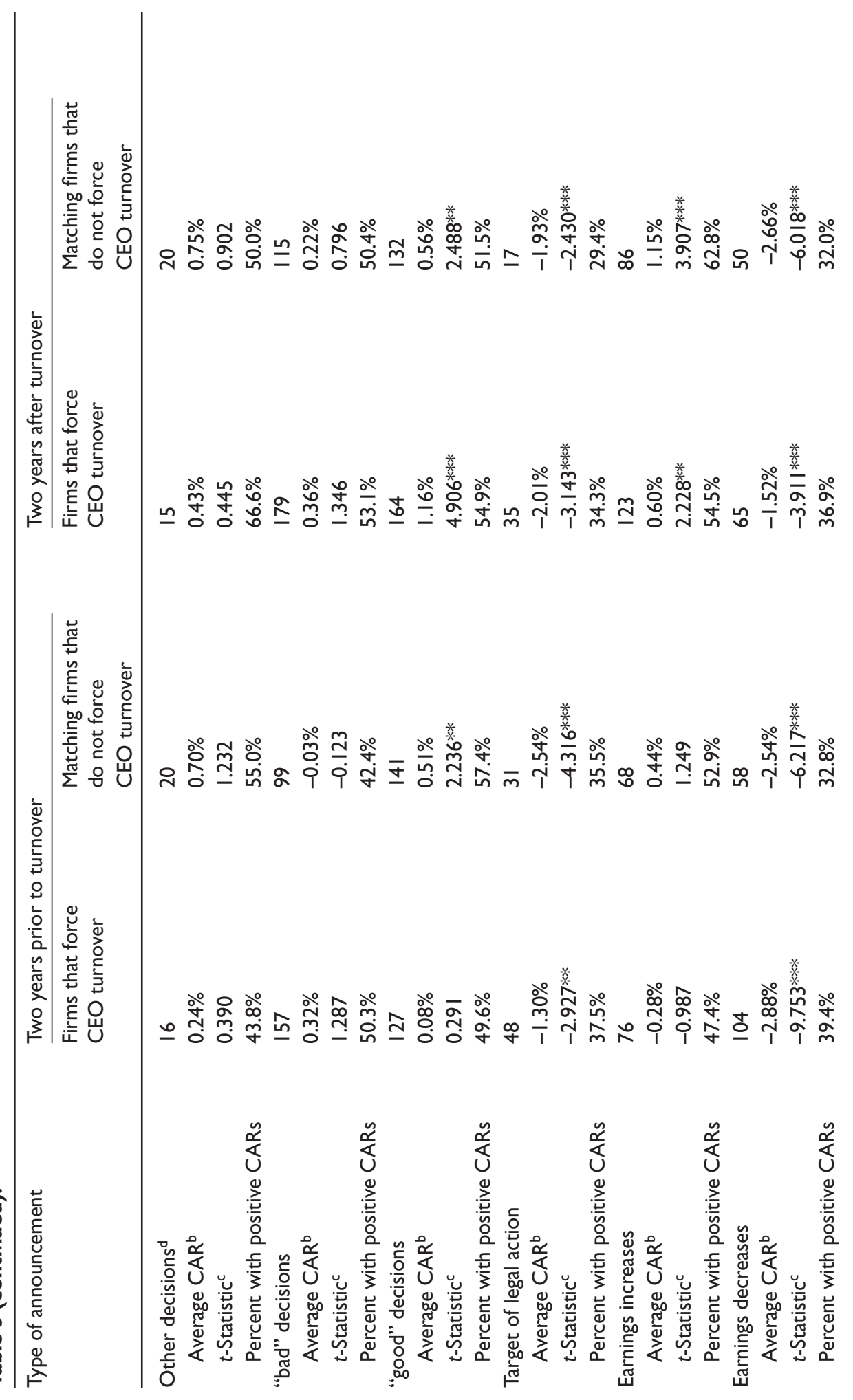




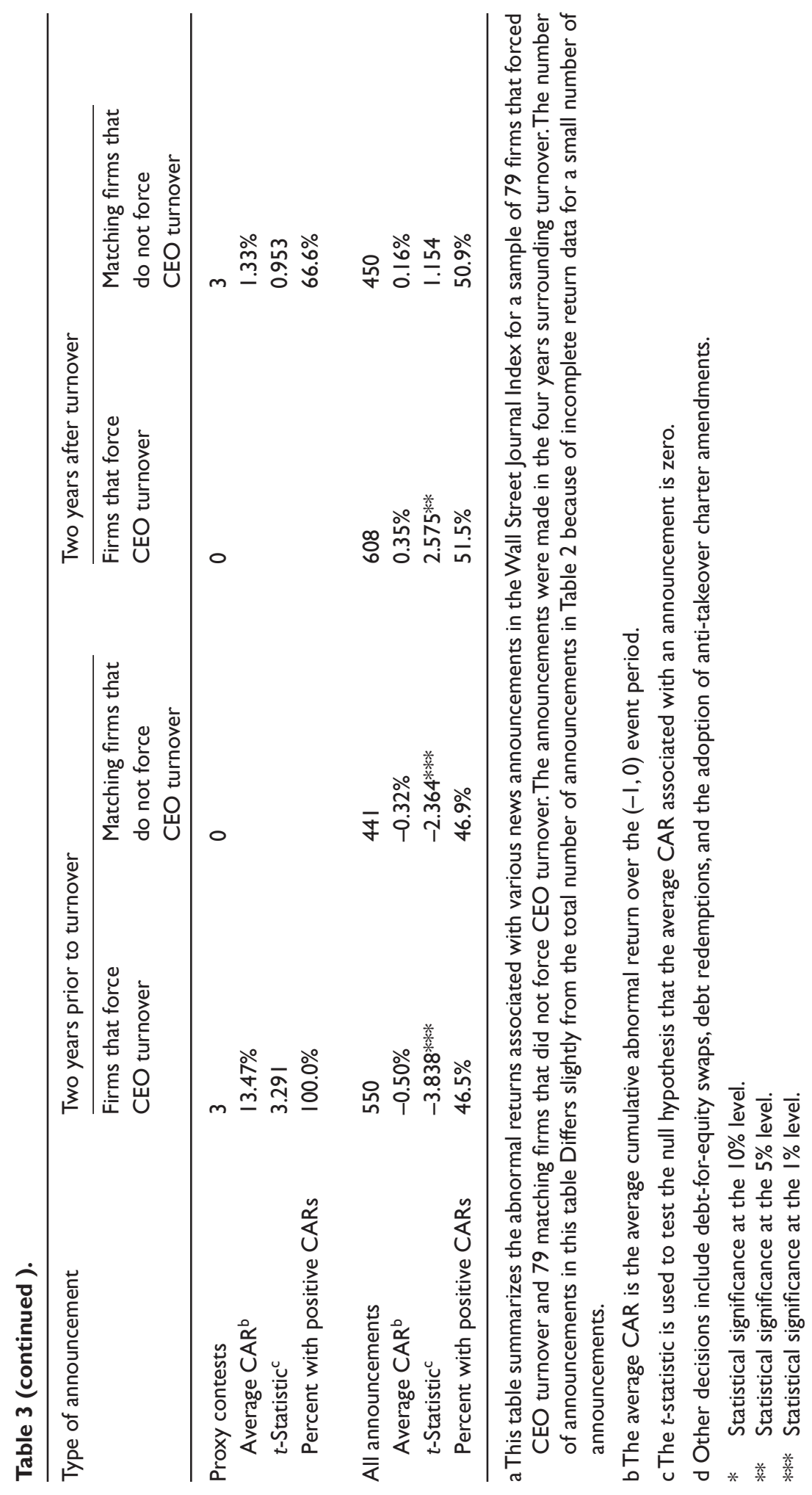


ments are also similar between samples, with both samples exhibiting significantly positive CARs for positive earnings announcements and stock buybacks. Earnings decreases and being the target of legal action, on the other hand, are associated with negative CARs for both the turnover and matched-sample firms. The only differences in response to news announcements across samples are significantly positive CARs for acquisitions and expansions, and new debt or loan extensions for the forced-turnover sample firms and insignificant CARs for the matched-sample firms. However, as in the pre-turnover announcements, none of these differences are statistically significant.

Contrary to our expectations, the results indicate little evidence of differences between the CARs associated with WSJ stories about the forced-turnover sample firms and the CARs associated with matched-sample firms before or after turnover. The market response to the decisions announced by the forced-turnover sample firms is not viewed as being value decreasing relative to the decisions announced by matched-sample firms. In other words, it does not appear that CEOs in the forced-turnover sample make decisions that are considered unexpectedly poor by the market prior to being forced from office.

\subsection{Analysis of news announcements surrounding forced CEO turnover}

Given that the market response to announcements by the forced-turnover and matched-sample firms do not significantly differ prior to forced turnover, we further analyze the type and frequency of news announcements for each sample. The greater number of announcements by the forced-turnover sample, as shown in Table 2, suggests that either the forced-turnover sample had a greater number of news events or the WSJ published a greater percentage of the turnover-sample news events. In an effort to test whether differences in the number of news stories are statistically significant, we perform paired difference tests on the average number of the various types of announcements. The results of this analysis are shown in Tables 4 and 5.

Table 4 reveals differences in the number of WSJ announcements of manager decisions. Prior to turnover, forced-turnover firms are the subjects of a greater number of news stories about manager decisions than the matched firms although the difference is not statistically significant. However, the forced-turnover sample firms are the subjects of a significantly greater number of WSJ stories about "bad" decisions before turnover relative to the matched-sample firms. The significantly greater number of "bad" decision announcements can be attributed, in a large part, to the significantly greater number of news stories associated with asset sales, layoffs, and downsizing. As a result of these decisions, the median annual growth in assets, sales, and number of employees during the two years that precede the year of turnover are $4.2 \%, 1.3 \%$, and $-0.3 \%$, respectively, for the forced-turnover firms. These growth figures are much smaller than the growth experienced by the matched sample, which had median annual growth in assets, sales, and number of employees during the same two years of $8.4 \%, 6.4 \%$, and $1.1 \%$, respectively.

Following turnover, forced-turnover sample firms continue to be the subjects of a greater number of WSJ articles about "bad" decisions than the matched sam- 


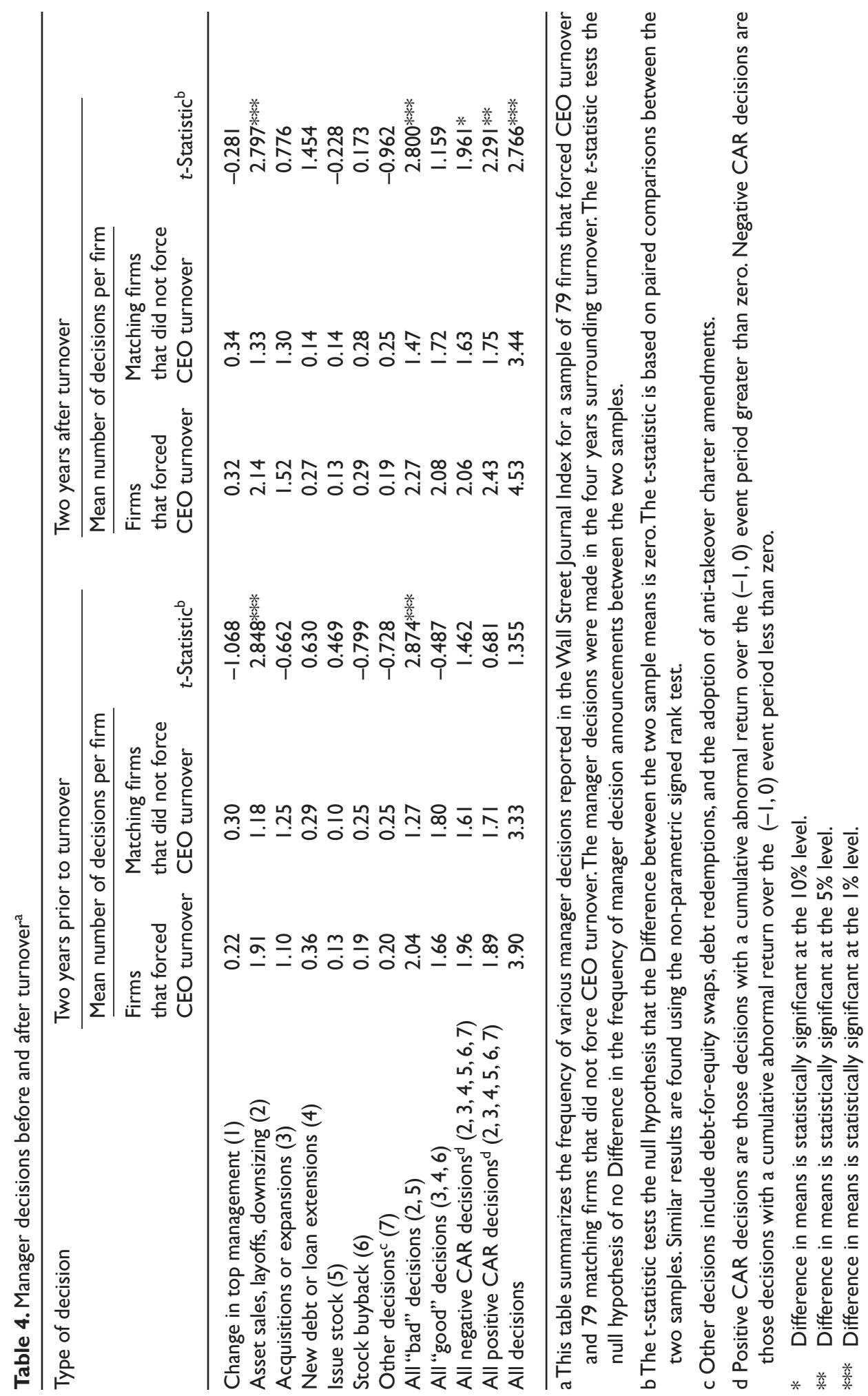




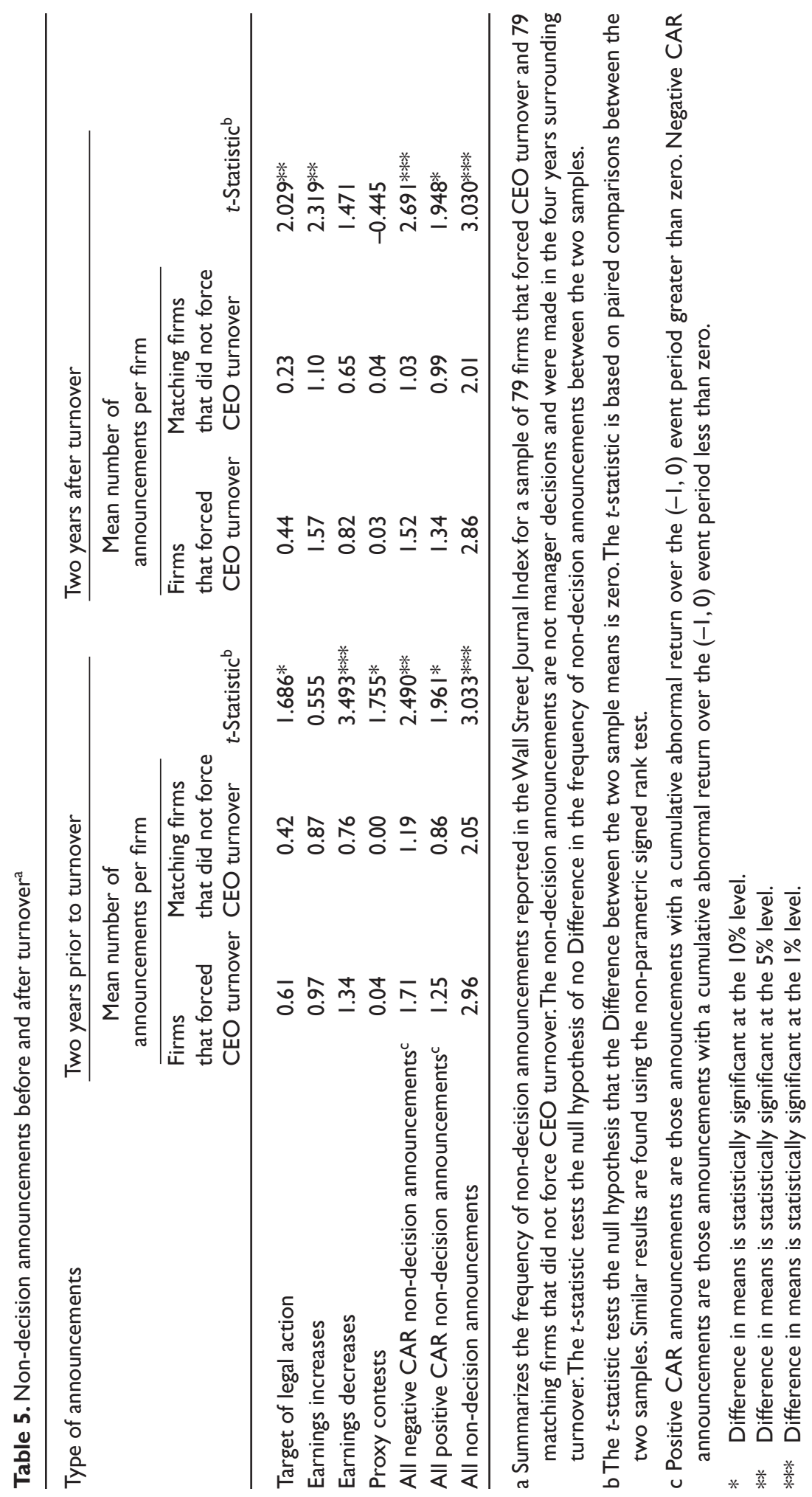


ple. However, while the forced-turnover sample firms continue to be the subjects of a significantly greater number of news stories about asset sales, layoffs, and downsizing, they are also the subjects of a greater number of news stories that generate positive CARs. ${ }^{18}$

Table 5 reports differences in the number of non-decision announcements in the WSJ. Prior to turnover, the forced-turnover sample firms are the subjects of a significantly greater number of WSJ announcements of being the target of legal action, earnings decreases, and proxy contests. The greater number of earnings decrease announcements is of particular interest because of the similar performance of the turnover and matched-sample firms. All else equal, we would expect to observe a similar number of earnings decrease announcements for the two groups of firms. The greater number of these announcements for the forcedturnover sample suggests that the performance of the forced-turnover sample was more closely monitored by the WSJ.

The greater number of WSJ announcements about the forced-turnover firms being the target of legal action may suggest that managers of these firms behave unethically and may be one reason for the increased scrutiny by the financial press. However, according to the results of a recent study by Agrawal et al. (1999), it is unlikely that the legal action explains the incidence of forced CEO turnover in these firms. They find little evidence that the managers of firms that are charged with fraud have an increased likelihood of losing their jobs. ${ }^{19}$

The greater number of WSJ stories about proxy contests in the forced-turnover sample suggests that the managers of these firms may have been under greater pressure to resign than their matched sample counterparts for reasons other than WSJ coverage. The results of the analysis that follows are qualitatively unchanged, however, when these firms are excluded from the analysis.

Following turnover, forced-turnover firms are the subjects of a significantly greater number of news stories regarding earnings increases. Differences in the number of stories about earnings decreases are not significant after turnover. Overall, these results suggest that while the WSJ continues to give greater scrutiny to the forced-turnover firms after turnover, the reporting appears to be more favorable. Further, the results suggest that although matchedsample firms were in the same industry, of similar size, and performing similarly, forced-turnover sample firms were under greater scrutiny by the financial press.

18 Khanna and Poulsen (1995) find that the Chapter 11 firms that experience turnover announce more downsizing decisions. Weisbach (1995) investigates the incidence of divestitures following CEO turnover and, finds evidence of an increased likelihood of divestitures following CEO turnover. The results of this study are consistent with Weisbach and Khanna and Poulsen, but also show an increased incidence of asset sales, layoffs, and downsizing prior to turnover.

19 More detailed analysis of the legal actions indicates that the differences between the turnover and matched firms are not due to increased allegations of fraud or misconduct among the forced-turnover firms. Prior to turnover, both the turnover firms and the matched firms are the subjects of seven news items concerning allegations of fraud. 


\subsection{Logit analysis of CEO turnover}

A potential limitation of the pair-wise analysis reported in Tables 4 and 5 is the inability to control for other factors beyond the matching criteria that may impact the likelihood of CEO turnover. For example, Table 1 indicates that, although the overall performance was similar between the two samples, turnover firms experience a greater number of large earnings declines during the eight quarters prior to turnover. It is reasonable to expect the WSJ to report more frequently on large earnings declines. Therefore, the greater reporting on the performance of the turnover firms may be due to large declines in earnings. Further, it is possible that the additional WSJ coverage of forced-turnover firms may be symptomatic of operating problems at these firms rather than contributing to the likelihood of CEO turnover.

To control for these possibilities and more formally examine the relation between WSJ coverage and forced CEO turnover, we estimate a logit model with a dependent variable equal to one for the forced-turnover firms and zero for the matching firms. A potential concern associated with this type of analysis is the unequal sampling rates from firms that force CEO turnover and those that do not. Maddala (1991) points out, however, that "the coefficients of the explanatory variables are not affected by the unequal sampling rates from the two groups. It is only the constant term that is affected." According to Maddala, the same cannot be said of the probit model. The purpose of this analysis is not to develop a model for predicting CEO turnover, but to determine the causes of turnover, so it is appropriate to use a choice-based sample and estimate a logit model.

We estimate several versions of the logit model. In all of the versions, we control for firm size (using the natural log of sales), outside board membership (using the percent of the board of directors that consists of independent outside directors), and inside ownership (using the percent of firm equity owned by the officers of the firm). ${ }^{20}$ The results of the logit regressions are shown in Table 6.

The first version of the logit model, Model 1, includes the number of quarters with greater than a $50 \%$ decline in earnings as an explanatory variable. We include this variable in the analysis for two reasons. First, Table 1 shows differences in this variable between the turnover and matched samples. Second, our primary interest is in how WSJ reporting on poor firm performance affects the likelihood of CEO turnover and we include a measure of firm performance to control for the correlation between WSJ reporting on firm performance and the level of firm performance. The measure of firm performance we have chosen should be more closely related to WSJ reporting than other measures. ${ }^{21}$ Not surprisingly, the coefficient on this performance measure is positive and statistically significant, sug-

20 We considered several other potential control variables, including CEO age, institutional ownership, board size, and other measures of firm size. None of these variables were significant in any of our regressions and did not have any notable impact on other coefficients.

21 This measure of firm performance is more highly correlated with the number of WSJ news items about poor firm performance than the other measures of performance shown in Table 1. However, the correlation coefficient is only 0.20 with a $P$-value of 0.012 . 
gesting that those firms with the greatest number of large declines in earnings are more likely to experience forced CEO turnover.

It is surprising that none of our control variables are significant in any of the models shown in Table 6. Inside ownership has the expected sign, but is not statistically significant at conventional levels. The lack of significance for the natural log of sales and outside board membership may be explained, in part, by the matching criteria. Firm size was one of the matching criteria and outside board membership tends to vary more between industries than within industries. Given that our matching firms are drawn from the same industry as the turnover firms, it is not unusual that the board composition of the turnover firms and matched firms are similar.

In Model 2 we exclude the performance measure from Model 1 and include the number of WSJ news items about a decline in earnings. Model 3 includes both variables. The coefficient on the number of WSJ news items about a decline in earnings is positive and statistically significant even after controlling for the level of firm performance. This suggests that while poor firm performance increases the likelihood of CEO turnover, the likelihood of CEO turnover is even greater when the WSJ is reporting on the firm's performance, consistent with the pairwise comparisons made in Tables 4 and $5 .^{22}$

Models 4-6 assess whether the observed relation between the number of WSJ news items about a decline in earnings and forced CEO turnover is spurious. It is possible that the additional coverage of forced-turnover firms is symptomatic of operating problems at these firms rather than contributing to the likelihood of CEO turnover. Table 4 indicates that the turnover firms made more "bad" decisions, which is due primarily to the greater number of asset sales, layoffs, and downsizing decisions. We include the number of these two types of decisions in Models 4 and 5 to assess whether these decisions, which are indicative of operating problems, increase the likelihood of CEO turnover. Included in Model 6 is the number of negative CAR decisions announced in the WSJ.

The results shown in Table 6 indicate that, after controlling for firm performance and the number of WSJ news items about a decline in earnings, the manager-decision variables do not have a statistically significant impact on the likelihood of CEO turnover. Further, the coefficient on the number of WSJ news items about a decline in earnings is still statistically significant. ${ }^{23}$ These results are consistent with Khanna and Poulsen (1995) and suggest that the CEOs in our sample were fired for reasons other than the decisions they made. ${ }^{24}$ In sum, the results

22 We estimated several versions of Table 6 to investigate the sensitivity of our results to the choice of the $50 \%$ decline in earnings threshold and potential seasonality in this measure. In all cases, the results with respect to the "number of news items about a decline in earnings" variable are qualitatively unchanged. The results of this sensitivity analysis are available from the authors.

23 It should be noted that we cannot completely rule out the possibility that the "number of WSJ stories about a decline in earnings" variable is somehow capturing differences in firm performance or operating problems despite our efforts to control for these differences.

24 When we exclude "the number of WSJ news items about a decline in earnings" from Models $4-7$, the coefficients on the other WSJ news item variables are still not statistically significant. 
Table 6. Logit regression results ${ }^{\mathrm{a}}$

\begin{tabular}{|c|c|c|c|c|c|c|c|}
\hline \multirow{2}{*}{$\begin{array}{l}\text { Explanatory variables } \\
\text { (measured prior to turnover) }\end{array}$} & \multicolumn{7}{|c|}{ Dependent variable: Forced CEO turnover } \\
\hline & Model I & Model 2 & Model 3 & Model 4 & Model 5 & Model 6 & Model 7 \\
\hline Constant & $\begin{array}{l}0.182 \\
(0.155)\end{array}$ & $\begin{array}{l}1.268 \\
(1.074)\end{array}$ & $\begin{array}{c}0.703 \\
(0.575)\end{array}$ & $\begin{array}{c}0.974 \\
(0.779)\end{array}$ & $\begin{array}{c}\text { I.0II } \\
(0.804)\end{array}$ & $\begin{array}{c}0.863 \\
(0.684)\end{array}$ & $\begin{array}{l}0.793 \\
(0.644)\end{array}$ \\
\hline Natural log of sales & $\begin{array}{l}-0.019 \\
(-0.144)\end{array}$ & $\begin{array}{l}-0.139 \\
(-1.041)\end{array}$ & $\begin{array}{l}-0.103 \\
(-0.752)\end{array}$ & $\begin{array}{l}-0.143 \\
(-1.001)\end{array}$ & $\begin{array}{l}-0.146 \\
(-1.019)\end{array}$ & $\begin{array}{l}-0.131 \\
(-0.885)\end{array}$ & $\begin{array}{l}-0.120 \\
(-0.860)\end{array}$ \\
\hline Outside board membership & $\begin{array}{l}-0.950 \\
(-0.914)\end{array}$ & $\begin{array}{l}-0.812 \\
(-0.792)\end{array}$ & $\begin{array}{l}-1.146 \\
(-1.082)\end{array}$ & $\begin{array}{l}-1.243 \\
(-1.168)\end{array}$ & $\begin{array}{l}-1.255 \\
(1.178)\end{array}$ & $\begin{array}{l}-1.183 \\
(-1.1 \mid 4)\end{array}$ & $\begin{array}{l}-1.162 \\
(-1.095)\end{array}$ \\
\hline Inside ownership & $\begin{array}{l}-5.053 \\
(-1.364)\end{array}$ & $\begin{array}{l}-5.555 \\
(-1.534)\end{array}$ & $\begin{array}{l}-5.082 \\
(-1.337)\end{array}$ & $\begin{array}{l}-5.138 \\
(-1.360)\end{array}$ & $\begin{array}{l}-5.092 \\
(-1.348)\end{array}$ & $\begin{array}{l}-5.169 \\
(-1.364)\end{array}$ & $\begin{array}{l}-5.242 \\
(-1.358)\end{array}$ \\
\hline $\begin{array}{l}\text { Number of quarters with greater } \\
0.367 * * *\end{array}$ & $0.4 I 4 * * *$ & & $0.366 * * *$ & $0.345^{* *}$ & $0.345^{* *}$ & $0.363^{* * *}$ & \\
\hline than a $50 \%$ decline in earnings & $(3.065)$ & & $(2.672)$ & $(2.477)$ & $(2.479)$ & $(2.640)$ & $(2.677)$ \\
\hline $\begin{array}{l}\text { Number of WSJ news items } \\
\text { about a decline in earnings }\end{array}$ & & $\begin{array}{l}0.339 * * * \\
(2.582)\end{array}$ & $\begin{array}{l}0.267 * * \\
(2.002)\end{array}$ & $\begin{array}{l}0.227 * \\
(1.647)\end{array}$ & $\begin{array}{l}0.228 * \\
(1.656)\end{array}$ & $\begin{array}{l}0.25 \mathrm{I} * \\
(\mathrm{I} .838)\end{array}$ & $\begin{array}{r}0.245^{*} \\
(1.792)\end{array}$ \\
\hline $\begin{array}{l}\text { Number of "bad" decisions } \\
\text { announced in the WSJ }\end{array}$ & & & & $\begin{array}{c}0.090 \\
(1.008)\end{array}$ & & & \\
\hline $\begin{array}{l}\text { Number of asset sales, layoffs, and } \\
\text { downsizings announced in the WSJ }\end{array}$ & & & & & $\begin{array}{c}0.091 \\
(1.000)\end{array}$ & & \\
\hline $\begin{array}{l}\text { Number of negative CAR } \\
\text { decisions announced in the WSJ }\end{array}$ & & & & & & $\begin{array}{c}0.048 \\
(0.498)\end{array}$ & \\
\hline $\begin{array}{l}\text { Number of legal actions against } \\
\text { the firm announced in the WSJ }\end{array}$ & & & & & & & $\begin{array}{l}0.127 \\
(0.703)\end{array}$ \\
\hline $\begin{array}{l}\text { Number of observations } \\
\text { Chi-square }\end{array}$ & $\begin{array}{l}156 \\
12.4^{* *}\end{array}$ & $\begin{array}{l}156 \\
10.2^{*}\end{array}$ & $\begin{array}{l}156 \\
16.7 * * *\end{array}$ & $\begin{array}{l}156 \\
17.8^{* * * *}\end{array}$ & $\begin{array}{l}156 \\
17.8 * * *\end{array}$ & $\begin{array}{l}156 \\
17.0 * * *\end{array}$ & $\begin{array}{l}156 \\
17.2 * * *\end{array}$ \\
\hline
\end{tabular}

a Logit regression results (and $t$-statistics) of the likelihood of forced CEO turnover for a sample of 79 firms that forced CEO turnover and a matched sample of 79 firms that did not force CEO turnover. The natural log of sales is measured at the end of the fiscal year prior to turnover. Outside board membership is the percentage of the board of directors that is comprised of independent outsiders. Inside ownership is the percentage of equity owned by the officers of the firm. Both of these variables are taken from the last proxy statement filed before CEO turnover. The number of quarters with greater than a $50 \%$ decline in earnings and the number of WSJ news items are measured during the two years prior to CEO turnover. One of the turnover firms and one of the matched firms have missing data for the decline in earnings variable and are not included in the analysis.

* Parameter estimate is statistically significant at the $10 \%$ level.

** Parameter estimate is statistically significant at the $5 \%$ level.

*** Parameter estimate is statistically significant at the $1 \%$ level

shown in Models 4-6 of Table 6 suggest that WSJ reporting on poor firm performance increases the likelihood of CEO turnover even after controlling for the level of performance and other indicators of operating problems at the firm. 
Table 7. Logit regression results with alternative performance measures

\begin{tabular}{|c|c|c|c|c|c|}
\hline \multirow{2}{*}{$\begin{array}{l}\text { Explanatory variables } \\
\text { (measured prior to turnover) }\end{array}$} & \multicolumn{5}{|c|}{ Dependent variable: Forced CEO turnover } \\
\hline & Model 3A & Model 3B & Model 3C & Model 3D & Model 3E \\
\hline Constant & $\begin{array}{c}1.278 \\
(1.077)\end{array}$ & $\begin{array}{l}1.431 \\
(1.153)\end{array}$ & $\begin{array}{c}0.721 \\
(0.469)\end{array}$ & $\begin{array}{l}1.149 \\
(0.914)\end{array}$ & $\begin{array}{c}1.106 \\
(0.877)\end{array}$ \\
\hline Natural log of sales & $\begin{array}{l}-0.131 \\
(-0.970)\end{array}$ & $\begin{array}{l}-0.166 \\
(-1.178)\end{array}$ & $\begin{array}{l}-0.093 \\
(-0.512)\end{array}$ & $\begin{array}{l}-0.126 \\
(-0.893)\end{array}$ & $\begin{array}{l}-0.134 \\
(-0.993)\end{array}$ \\
\hline Outside board membership & $\begin{array}{l}-0.902 \\
(-0.871)\end{array}$ & $\begin{array}{l}-0.659 \\
(-0.609)\end{array}$ & $\begin{array}{l}-0.067 \\
(-0.043)\end{array}$ & $\begin{array}{l}-0.806 \\
(-0.786)\end{array}$ & $\begin{array}{l}-0.851 \\
(-0.831)\end{array}$ \\
\hline Inside ownership & $\begin{array}{l}-5.414 \\
(-1.488)\end{array}$ & $\begin{array}{l}-7.203^{*} \\
(-1.692)\end{array}$ & $\begin{array}{l}-8.177 \\
(-1.376)\end{array}$ & $\begin{array}{l}-5.534 \\
(-1.524)\end{array}$ & $\begin{array}{l}-5.168 \\
(-1.402)\end{array}$ \\
\hline $\begin{array}{l}\text { Number of WSJ news items } \\
\text { about a decline in earnings }\end{array}$ & $\begin{array}{l}0.338 * * * \\
(2.584)\end{array}$ & $\begin{array}{l}0.314 * * \\
(2.373)\end{array}$ & $\begin{array}{c}0.222 \\
(1.322)\end{array}$ & $\begin{array}{l}0.33 \mathrm{I} * * \\
(2.48 \mathrm{I})\end{array}$ & $\begin{array}{l}0.325^{* *} \\
(2.477)\end{array}$ \\
\hline Industry-adjusted ROAA ${ }^{a}$ & $\begin{array}{c}-0.015 \\
(-0.674)\end{array}$ & & & & \\
\hline $\begin{array}{l}\text { Change in industry-adjusted } \\
\text { ROAA }^{\mathrm{a}}\end{array}$ & & $\begin{array}{l}0.022 \\
(0.505)\end{array}$ & & & \\
\hline $\begin{array}{l}\text { Average quarterly earnings } \\
\text { surprise }^{\text {b }}\end{array}$ & & & $\begin{array}{l}-0.051 \\
(-0.161)\end{array}$ & & \\
\hline $\begin{array}{l}\text { Average annual market-adjusted } \\
\text { stock returns }{ }^{c}\end{array}$ & & & & $\begin{array}{l}-0.227 \\
(-0.275)\end{array}$ & \\
\hline $\begin{array}{l}\text { Number of quarters with a } \\
\text { decline in earnings }{ }^{d}\end{array}$ & & & & & $\begin{array}{l}0.035 \\
(0.231)\end{array}$ \\
\hline Number of observations & 158 & 144 & 76 & 158 & 156 \\
\hline Chi-square & $10.7 *$ & $10.4 *$ & 4.7 & $10.3 *$ & 9.2 \\
\hline
\end{tabular}

a Pre-turnover return on average assets (ROAA) is measured during the last two years ending prior to CEO turnover. It is industry adjusted by Differencing from industry medians. Industries are based on two-digit SIC codes. Changes in ROAA are based on changes in the industry-adjusted performance measures during the two years prior to CEO turnover. Calculating the changes requires three years of pre-turnover data, which was not available for some of the firms.

b Earnings surprise data are the percentage Difference between actual quarterly earnings and forecasted earnings. Forecasted earnings are from Zachs Investment Research. Quarterly earnings forecasts were available for only 38 matched pairs.

c Stock returns are market-adjusted using the CRSP NYSE/AMEX/Nasdaq value-weighted index.

$d$ The number of quarters with a decline in earnings is measured during the eight quarters that end prior to CEO turnover. One of the turnover firms and one of the matched firms have missing data for the decline in earnings variable and are not included in the analysis.

* Parameter estimate is statistically significant at the $10 \%$ level.

** Parameter estimate is statistically significant at the $5 \%$ level.

*** Parameter estimate is statistically significant at the $1 \%$ level.

Table 5 indicates that there were more stories about the turnover firms being the target of legal actions. To determine whether this is affecting the likelihood of CEO turnover, we include the number of WSJ news items about the firm being 
the target of legal action in Model 7 of Table 6. The results indicate that this variable is not statistically significant in explaining CEO turnover. This is consistent with Agrawal et al. (1999) who find little evidence that the managers of firms that are charged with fraud have an increased likelihood of losing their jobs. A more detailed analysis based on a breakdown of the different types of legal actions (alleged fraud; shareholder class-action lawsuits; copyright, patent, trademark or licensing infringement; antitrust lawsuits; environmental lawsuits; wrongful termination lawsuits; and other legal actions) fails to yield more meaningful results. ${ }^{25}$

\subsection{Logit analysis of CEO turnover using alternative performance measures}

The results shown in Table 6 suggest a strong relation between WSJ reporting on poor firm performance and the likelihood of CEO turnover, even after controlling for the level of firm performance. Given the possibility that WSJ reporting on firm performance might be capturing the impact of firm performance on CEO turnover and not the impact of scrutiny by the financial press, we investigate how other performance measures affect the logit results.

The results of estimating Model 3 using alternative performance measures are reported in Table 7. Surprisingly, none of our other performance measures were statistically significant. This is probably due to the matching criteria we used. Our matching firms had similar stock price performance during the two years prior to turnover, so it is not surprising that this and other performance measures were not statistically significant in explaining forced CEO turnover. In all but one version of Model 3 is the number of WSJ news items about a decline in earnings statistically significant. The exception is the model that includes the average quarterly earnings surprise as an explanatory variable. The lack of significance may be due to insufficient data, however, as we were only able to estimate this version of the model for 76 firms (38 turnover firms and their matching firms).

\section{Conclusion}

We examine differences in WSJ news articles for a sample of firms that forced CEO turnover and a sample of matching firms that did not force turnover. We find that the firms that force CEO turnover are the subjects of a greater frequency of news announcements, especially news articles about declining earnings, relative to their matched sample counterparts for the two years prior to the turnover. Despite this increased scrutiny of the forced-turnover sample firms, the market's response to the decisions announced by the forced-turnover sample firms were similar to those announced by the matched-sample firms. This finding suggests that senior managers of the forced-turnover sample did not make inferior or relatively unanticipated decisions but that increased scrutiny of the firm's performance pressured the board of directors to make changes in the firm's senior management. 
The increased scrutiny of the forced-turnover sample firms continues postturnover as evidenced by a continued greater frequency of news announcements relative to the matched-sample firms. However, the frequency of news announcements about increased earnings is significantly greater after turnover for the forced-turnover sample firms than the comparable set of announcements for the matched-sample firms.

The results are consistent with several arguments about how the financial press can influence corporate governance. First, to the extent that financial press coverage influences the investing public's assessment of a firm's value, the board of directors may respond to negative coverage by forcing CEO turnover in an effort to avoid a further decline in firm value. Second, if financial press coverage of poor firm performance exacerbates operating problems by harming relations with suppliers, customers, and lenders, the board may remove the CEO in an effort to improve these relations. Third, if directors perceive media coverage of poor firm performance as damaging their reputations as experts in decision control, they may respond by forcing $\mathrm{CEO}$ turnover in an effort to salvage their reputations. Finally, the board of directors may force CEO turnover if they view the CEO as ineffective in managing the media's coverage of the firm.

Regardless of which of these non-mutually exclusive arguments explains the results, it appears that reporting by the financial press improves corporate governance. This important result suggests that the financial press (along with activist institutional investors, outside blockholders, and takeover markets) helps to mitigate the free rider problem associated with diffusely owned corporations.

\section{Acknowledgments}

We would like to thank Dae-Lyong Kim and Jeremy Brown for their research assistance. We are grateful for helpful comments and suggestions from Sherry Jarrell, Bob Parrino, Patricia Sias, Rick Sias, Tom Zorn, two anonymous reviewers for Journal of Banking \& Finance, and seminar participants at the 1998 Southern Finance Association meetings, the $1997 \mathrm{Fi}$ nancial Management Association meetings and the University of Nebraska-Lincoln.

\section{References}

Agrawal, A., Jaffe, J. F. and Karpoff, J. M., 1999. Management turnover and governance changes following the revelation of fraud. Journal of Law and Economics 42, pp. 309-342.

Akhigbe, A., Easterwood, J. C. and Pettit, R. R., 1997. Wealth effects of corporate debt issues: The impact of issuer motivations. Financial Management 26, pp. 32-47.

Asquith, P. and Mullins Jr., D. W., 1986. Equity issues and offering dilution. Journal of Financial Economics 15, pp. 61-89.

Baysinger, B. D. and Zardkoohi, A., 1986. Technology, residual claimants and corporate control. Journal of Law, Economics, and Organization 2, pp. 339-349.

Blackwell, D. W., Marr, M. W. and Spivey, M. F., 1990. Plant-closing decisions and the market value of the firm. Journal of Financial Economics 26, pp. 277-288. 
Blackwell, D. W., Farrell, K. A., 1999. Changes in compensation following CEO turnover. University of Nebraska-Lincoln Working Paper (December)

Brickley, J. A., Coles, J. L. and Terry, R. L., 1994. Outside directors and the adoption of poison pills. Journal of Financial Economics 35, pp. 371-390.

Brickley, J. A. and James, C. M., 1987. The takeover market, corporate board composition, and ownership structure: The case of banking. Journal of Law and Economics 30, pp. 161-180.

Brown, S. J. and Warner, J. B., 1985. Using daily stock returns: The case of event studies. Journal of Financial Economics 14, pp. 3-31.

Byrd, J. W. and Hickman, K. A., 1992. Do outside directors monitor managers? Evidence from tender offer bids. Journal of Financial Economics 32, pp. 195-221.

Cavender, G. and Mulcahy, A., 1998. Trial by fire: Media constructions of corporate deviance. Justice Quarterly 15, pp. 697-717.

Clark, R. N., 1989. SICs as delineators of economic markets. Journal of Business 62, pp. 17-31.

Denis, D. J. and Denis, D. K., 1994. Majority owner-managers and organizational efficiency. Journal of Corporate Finance 1, pp. 91-118.

Denis, D. J., Denis, D. K. and Sarin, A., 1997. Ownership structure and top executive turnover. Journal of Financial Economics 45, pp. 193-221.

Denis, D. J. and Serrano, J. M., 1996. Active investors and management turnover following unsuccessful control contests. Journal of Financial Economics 40, pp. 239-266.

Fama, E. F, 1980. Agency problems and the theory of the firm. Journal of Political Economy 88, pp. 134-145.

Fama, E. F. and Jensen, M. C., 1983. Separation of ownership and control. Journal of Law and Economics 27, pp. 301-325.

Farrell, K. A. and Whidbee, D. A., 2000. The consequences of forced CEO succession for outside directors. Journal of Business 73, pp. 597-628.

Flynn, F. J., 2000. No news is good news: The relationship between media attention and strike duration. Industrial Relations 39, pp. 139-160.

Gamson, W., 1992. Talking Politics, Cambridge University Press, New York.

Gilson, S. C., 1989. Management turnover and financial distress. Journal of Financial Economics 25, pp. 241-262.

Hermalin, B. E. and Weisbach, M. S., 1988. The determinants of board composition. Rand Journal of Economics 19, pp. 589-606.

James, C., 1987. Some evidence on the uniqueness of bank loans. Journal of Financial Economics 19, pp. 217-235.

Karpoff, J. M. and Lott Jr., J. R., 1993. The reputational penalty firms bear from committing criminal fraud. Journal of Law and Economics 36, pp. 757-802.

Khanna, N. and Poulsen, A. B., 1995. Managers of financially distressed firms: Villains or scapegoats?. Journal of Finance 50, pp. 919-939.

Lowenstein, L., 1996. Financial transparency and corporate governance: You manage what you measure. Columbia Law Review 96, pp. 1335-1362.

Lowenstein, L., 1999. Corporate governance and the voice of the paparazzi. The Center for Law and Economic Studies Working Paper No. 132

Maddala, G. S., 1991. A perspective on the use of limited-dependent and qualitative variables models in accounting research. The Accounting Review 66, pp. 788-807. 
Martin, K. J. and McConnell, J. J., 1991. Corporate performance, corporate takeovers, and management turnover. Journal of Finance 46, pp. 671-687.

Mikkelson, W. H. and Partch, M. M., 1997. The decline of takeovers and disciplinary managerial turnover. Journal of Financial Economics 44, pp. 205-228.

Murphy, K. and Zimmerman, J. L., 1993. Financial performance surrounding CEO turnover. Journal of Accounting and Economics 16, pp. 273-315.

Palmon, O., Sun, H. and Tang, A. P., 1997. Layoff announcements: Stock market impact and financial performance. Financial Management 26, pp. 54-68.

Pan, Z. and Kosicki, G. M., 1997. Priming and media impact on the evaluations of the president's performance. Communication Research 24, pp. 3-30.

Parrino, R., 1997. CEO turnover and outside succession: A cross-sectional analysis. Journal of Financial Economics 46, pp. 165-197.

Parrino, R., Sias, R. W., Starks, L. T., 2000. Voting with their feet: Institutional investors and CEO turnover. University of Texas at Austin Working Paper

Price, V., Tewksbury, D., 1997. News values and public opinion: A theoretical account of media priming and framing. In: Barnett, G., Boster, F. J. (Eds.), Progress in the Communication Sciences, JAI Press, Greenwich, CT, pp. 173-212

Price, V., Tewksbury, D. and Powers, E., 1997. Switching trains of thought: The impact of news frames on readers' cognitive responses. Communications Research 24, pp. 481-506.

Subrahmanyam, V., Rangan, N. and Rosenstein, S., 1997. The role of outside directors in bank acquisitions. Financial Management 26, pp. 23-36.

Sutton, R. I. and Galunic, D. C., 1996. Consequences of public scrutiny for leaders and their organizations. Research in Organizational Behavior 18, pp. 201-250.

Thompson II, R. B., Olsen, C. and Dietrich, J. R., 1987. Attributes of news about firms: An analysis of firm-specific news reported in the Wall Street Journal Index. Journal of Accounting Research 25, pp. 245-274.

Weisbach, M. S., 1988. Outside directors and CEO turnover. Journal of Financial Economics 20, pp. 431-460.

Weisbach, M. S., 1995. CEO turnover and the firm's investment decisions. Journal of Financial Economics 37, pp. 159-188.

Yau, J., Ferri, M. G. and Sugrue, T. F., 1994. An analysis of the Wall Street Journal's coverage of corporate news and the research design of event studies. Journal of Financial Research 42, pp. 161-173. 